\title{
Population structure and mating system of the Red-crested Korhaan (Lophotis ruficrista) in South Africa
}

Johann $\mathrm{H}$ van Niekerk

\begin{abstract}
Background: The mating system of the korhaans and bustards in southern Africa is either based on polygyny or monogamy. The Red-crested Korhaan (Lophotis ruficrista) has been described as polygynous but otherwise very little is known about its breeding biology. The aims were to describe the population structure and male behavior during breeding.

Methods: The data collected for this paper was mainly based on field transect surveys carried out in 2009, 2010 and 2011. The population structure of the Red-crested Korhaan in the temperate Borakalalo Game Reserve (BGR) was compared with that in the arid Molopo Nature Reserve (MNR) (both situated in the North West province of South Africa). The study was mainly conducted in the BGR but additional work was conducted in the MNR for comparison.

Results: The difference in mean group sizes between MNR (1.03) and BGR (1.07) was statistically not significant. Group sizes were not affected by climate despite the fact that the BGR received about $650 \mathrm{~mm}$ precipitation per annum and the MNR about $200 \mathrm{~mm}$. In both reserves the apparent sex ratios were skewed in favor of males (1:0.29 in the BGR and 1:0.1 in the MNR). The population was dispersed in a clumped manner which is ascribed to the formation of leks. Leks were positioned in open habitat while females invariably concealed themselves under cover.

Conclusions: The leks formed the pivot of the mating system of the Red-crested Korhaan and are identifiable social structures that field ecologists can use to monitor population stability.
\end{abstract}

Keywords: Lophotis ruficrista, Leks, Mating system, Dispersion, Group size

\section{Background}

The name "korhaan" is used in South Africa to denote the smaller bustard species (Hockey et al. 2005). The ecological behavior of bustards (genera: Neotis and Ardeotis) and korhaans (genera: Lophotis, Afrotis, Eupodotis and Lissotis) in Africa is poorly documented, yet these birds face many environmental threats (Broders et al. 2003). The range and density of a number of these species have been reduced by habitat fragmentation and modification, collision with infrastructure, disturbances and climate change (Hockey et al. 2005; Allan and Anderson 2010).

\footnotetext{
Correspondence: thirstland2@gmail.com
}

Department of Environmental Sciences, College of Agriculture and

Environmental Sciences, University of South Africa, PO Box 392, Pretoria 0003, South Africa
The mating system of the korhaans and bustards in southern Africa is either based on polygyny or monogamy (Hockey et al. 2005). The Red-crested Korhaan (Lophotis ruficrista, focus of this present study) has been described as polygynous but otherwise very little is known about its breeding biology (Kemp and Tarboton 1976). Recently van Niekerk (2014) provided a detailed account of its vocal repertoire and demonstrated that males call in clusters to attract females. There was constant chasing and competition between males in these clusters (van Niekerk 2014).

It should be noted that the Northern Black Korhaan (Afrotis afraoides) is also polygynous. Males gather in groups of 4-6 but territorial males repel intruders through chases. These males display to $2-3$ females simultaneously and their females also defend their own territories (Allan 
2005a). The Karoo Korhaan (Eupodotis vigorsii) is monogamous and lives in extended family groups or pairs. The group remains in a territory year round which is defended actively by the male (Allan 2005b). The Blue Korhaan (E. caerulescens) is also monogamous and lives in pairs or extended family groups in territories (Allan 2005c). Unlike the smaller korhaans, Ludwig's Bustard (Neotis ludwigii) and Kori Bustards (Ardeotis kori) form leks at regularly used sites. About 1-3 males may occur at a lek about $300 \mathrm{~m}$ apart. Ludwig's Bustard males defend their immediate display areas (Allan 2005d and 2005e).

The distribution of the Red-crested Korhaan (Lophotis ruficrista) is mainly limited to Namibia, Botswana, Zimbabwe and South Africa. It is not threatened but its habitat has been reduced by intensive agriculture in Swaziland and the north east of South Africa and by overgrazing in Zimbabwe (Allan 2005f). These birds are hunted by local people but very little information is available, or efforts made, to determine a sustainable harvesting strategy (Hitchcock et al. 1996; JH van Niekerk, personal observations).

Collecting information on the breeding biology and mating systems is a vital part of all studies of the population ecology of birds. Population structure is founded on social interaction among individuals which is essential to identify fitness, gene flow and spatial patterns required for conservation strategies (Green, 2004; Whitehead, 2008). In order to describe the population structure and mating system of the Red-crested Korhaan my aims were: 1) to provide basic information on group sizes, demography and dispersion in space and time and 2) to demonstrate that Red-crested Korhaan males form dispersed leks.

Leks are usually regarded as small clustered court areas where males gather to display and compete for females during the breeding season (Sutherland et al. 2004). According to Bradbury (1981) a lek possesses four inherent characteristics: 1) no male parental care; 2) males must aggregate to display; 3 ) females select a male from the lek to breed with and 4) males are the only resource that females find in a lek. However, Högland and Alatalo (1995) proposed the 'non-classical' lek which is known as the dispersed (or exploded) lek. Dispersed leks mean competing males are separated by considerable distances and females may indeed raise their offspring in these areas. In other words, there are more resources in the lek than just males as proposed by Bradbury (1981). According to Morales et al. (2001) dispersed leks are particularly characteristic of bustards.

\section{Methods}

Two reserves from two different climate regions were chosen for field work. The study was mainly conducted in the Borakalalo Game Reserve (BGR) but some additional work was carried out in the Molopo Nature Reserve
(MNR) for comparison. The $140 \mathrm{~km}^{2}$ BGR $\left(25^{\circ} 12^{\prime} \mathrm{S}\right.$, $27^{\circ} 49^{\prime}$ E) is situated in the North West province, South Africa. The vegetation is described as Western Sandy Bushveld (Mucina and Rutherford 2006). The climate is temperate with an annual rainfall of $\sim 650 \mathrm{~mm}$. The $244 \mathrm{~km}^{2} \mathrm{MNR}\left(25^{\circ} 47^{\prime} \mathrm{S}, 22^{\circ} 56^{\prime} \mathrm{E}\right)$ is in the same province, about $520 \mathrm{~km}$ from the BGR (see Figure 1). The vegetation is described as Molopo Bushveld with grass cover broken by patches of open desert sand (Mucina and Rutherford 2006). The climate is arid, with an annual rainfall of $\sim 200 \mathrm{~mm}$ (Chittenden et al. 2012). Both sites were proclaimed as reserves in the 1980s and the BGR still has degraded areas that are indicative of overgrazing by livestock.

The Red-crested Korhaan usually lives under relatively dense cover (Kemp and Tarboton 1976). However, preliminary field surveys were conducted in both reserves from 2000 to 2009; these revealed that the detectability of korhaans was not affected by the understory for a distance of $75 \mathrm{~m}$ from the transect/road. Males were vocal throughout the year (van Niekerk 2014). Females were sighted during winter in both reserves, but they became more elusive during the breeding season when ground cover was denser following summer rainfall; however, individuals were often heard during male-male calls. Vigorous responses to sound playback by males throughout the year, spontaneous sounds and the visual sighting of korhaans were used collectively to record individuals and groups on maps of both reserves during each transect route for this survey (Constantine 2013; see van Niekerk 2014 for details on sound recorders and methods).

Visually, males are distinguished from females by their two white breast patches and distinctly darker crown feathers, while females typically have a white band across the upper breast area and a spotted crown. Sub-adults generally resemble females, but are more speckled on the neck and back (Allan 2005f).

For the period of December 2009 to January 2011 Red-crested Korhaans were counted and observed along a fixed transect route (dirt road) in the BGR. This transect was traversed on 42 occasions. This was conducted three times per month (three transect surveys) totalling 140 hours. These three monthly surveys were carried out over a period of two days, conducted during two mornings (7:00-10:00) and one late afternoon (15:00-18:00) survey from a slow-moving vehicle $(8-10 \mathrm{~km} / \mathrm{h})$. The transect crossed through all major landscapes and habitat types including woodlands (mainly Terminalia sericea), along the southern shoreline of the Klipvoor Dam $(5 \mathrm{~km})$, in overgrazed areas, eroded areas, burnt areas and savannah (scattered trees with grasslands) in a southern section of the BGR (Figure 1). The transect was $20 \mathrm{~km}$ long with a width of $150 \mathrm{~m}$, that is $75 \mathrm{~m}$ on either side of a dirt road. The roads were quiet with an average of one other vehicle encountered every four hours. During traversing scanning 


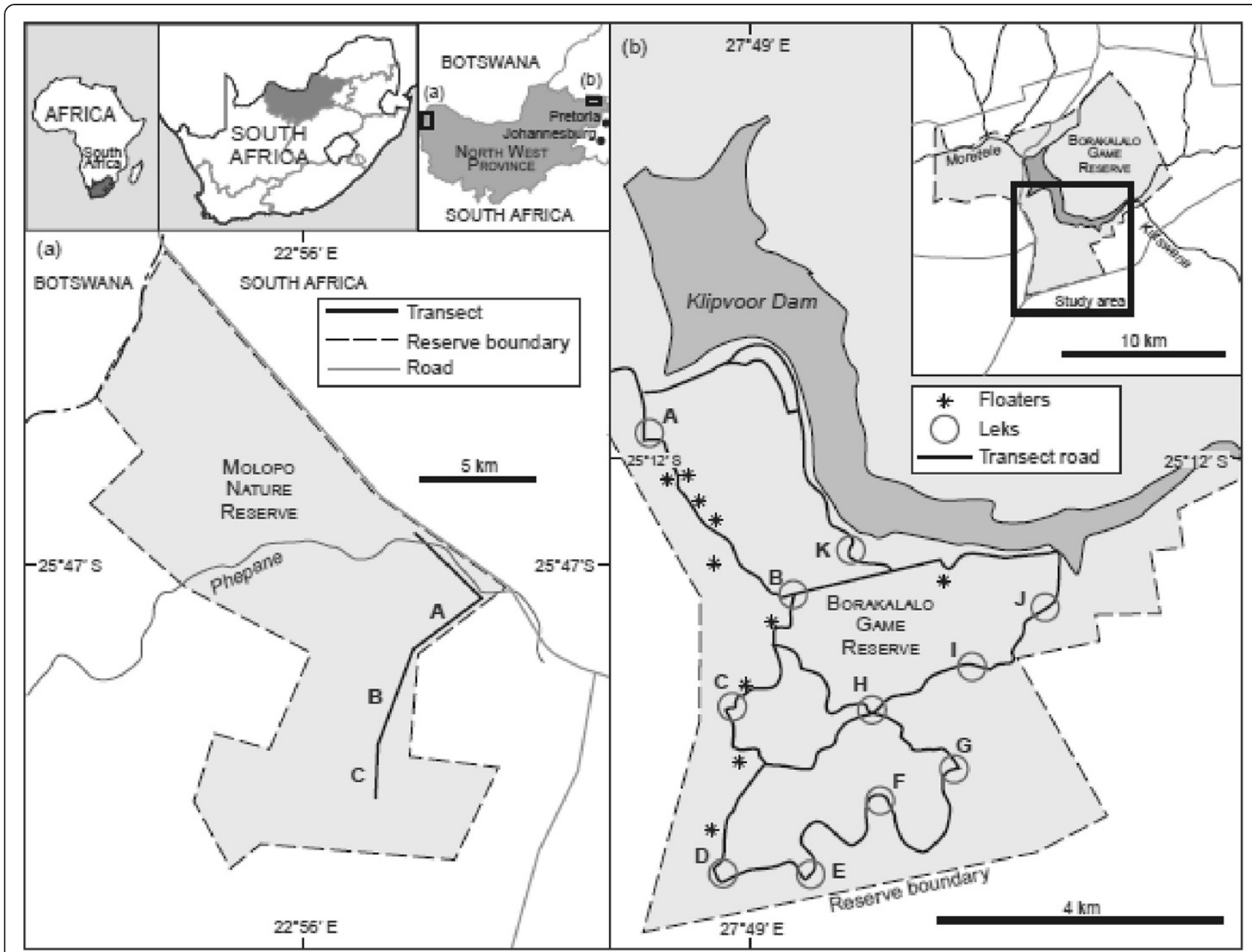

Figure 1 Two study sites in South Africa where the population ecology of the Red-crested Korhaan was studied. MNR = Molopo Nature Reserve ( $\mathbf{A}=$ neighboring farm; $\mathbf{B}$ office complex; $\mathbf{C}=$ water hole). $\mathbf{B G R}=$ Borakalalo Game Reserve. $\mathbf{A}$ to $\mathbf{K}$ (circles) = male clusters. $\mathbf{S}=$ floaters (single korhaan) appearing during the breeding season.

was conducted continuously from the vehicle and playback was done at $200 \mathrm{~m}$ intervals (Sutherland et al. 2004).

One hundred hours were also spent counting and observing Red-crested Korhaans in the MNR, which was visited during June 2009, December 2009, June 2010 and February 2011, with each visit lasting four days. This transect ( $150 \mathrm{~m}$ wide and $18 \mathrm{~km}$ long) was traversed on $21 \mathrm{oc}-$ casions in the mornings (7:00-10:00) and late afternoons (15:00-18:00) with a slow-moving vehicle $(8-10 \mathrm{~km} / \mathrm{h})$. The vegetation along the transect mainly consisted of acacia trees interspersed with scrubland and tallish grass. The middle sector of this transect traversed along a neighboring farm where bushes were removed to encourage the propagation of grassland (Figure 1A), then through the office complex of the reserve (Figure 1B) and finally ended at a water hole (Figure 1C). The scanning method used in the BGR was also applied here but fewer vehicles were encountered, about one per day.
The dispersion of korhaans was studied in order to determine how the population responded spatially to local environmental conditions. I used binoculars $(8 \times 43$ magnifications) and recorded the number of birds, determined sex and age composition of groups and plotted it on a map. A Colorado GPS was used to plot the position of all sighted korhaans. Theoretically, individual or group of birds in a population may be dispersed in one of three spatial patterns: 1) a clumped dispersion occurs when there is habitat/landscape heterogeneity or it may be a function of social forces such as grouping; 2) a uniform dispersion is normally associated with territoriality and 3) a random dispersion is associated with a nonpredictive pattern caused by fragmented habitats (cf. Odum 1971; Khan and Mian 2013). The density of korhaans was determined per fixed transect areas, i.e., 300 ha for the BGR and 270 ha for the MNR. Information on rainfall for the BGR was obtained from the park 
offices to correlate monthly rainfall with mean monthly group sizes but this correlation was not carried out for the MNR due to a limited number of observations. A group was defined as two or more korhaans with a "flock spread" of not more than $10 \mathrm{~m}$ between two furthest birds in the group.

\section{Results}

\section{Seasonal events}

Seasonal events of the Red-crested korhaan are explained in Additional file 1: Table S1. In the BGR three groups of three males each gathered from August onwards in relatively open habitats, e.g. previously overgrazed, degraded land. These gatherings were characterized by short chases between males and "honk-honk" sounds, but physical clashes were never observed. Males and females were observed answering each other's calls from September to October, which is the peak mating season in the BGR $(n=9)$, where male aerial displays were observed from September to December $(n=6)$. On three occasions these displays took place between a male and female that was engaged in reciprocal calling. However, aerial displays were also observed during January and March and in the MNR two displays were also recorded during June, which was outside the breeding season.

Active calling between males, from regular posts, took place from September to December in the BGR (Figure 2). Calling males were observed to turn their heads in order to direct sounds towards one another $(n=5)$. This period is regarded as the breeding season and coincides with egglaying dates from August- to December in the former Transvaal (Tarboton et al. 1987). From about February to August, single adult males (without other males heard nearby) were observed in the BGR population and relatively quiet, not peeping as often as they did during the breeding season from September to December when other males were responding (Figure 2; also see van Niekerk 2014).

Males and females did not form lasting pairs and no family groups were observed in either of the two reserves. A female and one offspring were observed nearby one of the traditional male clusters in the BGR. Clusters refer to male gatherings where they displayed and competed for females (see later under Clusters). In the BGR, four females were seen near males in the clusters (about 10 to $40 \mathrm{~m}$ away) between September and November. Two males raised their reddish crest feathers, which is typical courtship display behavior (Allan 2005f). During the displays females were not observed nearby (within $5 \mathrm{~m}$ of the displaying male) but were heard nearby. Twelve solitary young birds (more cryptically speckled than the parents) appeared in the BGR population from April to December, which suggest that they had left their mother's care at roughly the end of March (Table 1). In one case a juvenile korhaan was killed by a Pale Chanting Goshawk (Melierax canorus) while the juvenile foraged with its mother nearby a lek in the MNR during February 2011.

\section{Male/female visibility and sex ratios}

Of the 242 Red-crested Korhaans sighted in the BGR 172 (71\%) were positively sexed and of the 185 recorded in the MNR 125 (68\%) were positively sexed. The rest were partly shielded under cover or heard only. To judge from the birds that were positively sexed, the male to female ratio was skewed in favor of males: in the case of the BGR this was 1:0.29 and in the MNR the ratio was 1:0.10. Males were particularly visible during September to December in the BGR. They displayed their upright white breast spots and simultaneously produced calls

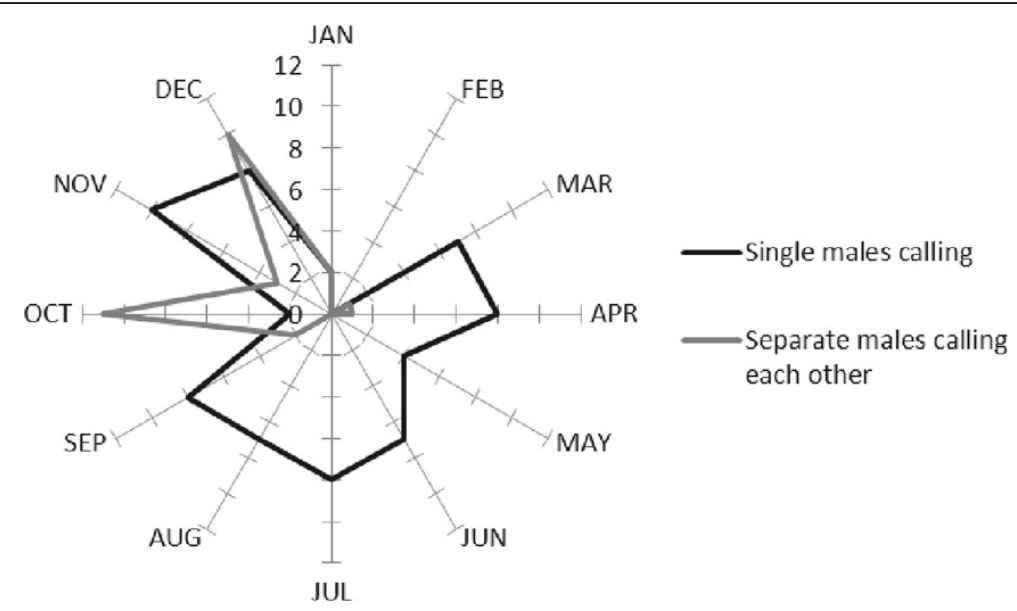

Figure 2 Number of single Red-crested Korhaan males calling (without response from other males) and male groups consisting of two or more males spaced about 30-50 m apart, that called (peep peep sounds) in response to one another, recorded in the Borakalalo Game Reserve during 2010. 
Table 1 Distribution of the Red-crested Korhaan counted across 11 clusters (male gatherings) (A-K, see also Figure 1) in the Borakalalo Game Reserve during monthly transect surveys (2010)

\begin{tabular}{|c|c|c|c|c|c|c|c|c|c|c|c|c|c|}
\hline & & Jan & Feb & Mar & Apr & May & Jun & Jul & Aug & Sep & Oct & Nov & Dec \\
\hline \multirow[t]{4}{*}{$A$} & Male & 1 & & & & 2 & 1 & 1 & & 1 & 2 & 1 & 2 \\
\hline & Female & & & & & & & 1 & & & & & 1 \\
\hline & Young & & & & & & & & & & 2 & & 1 \\
\hline & $?$ & & & & & & & & & & & & \\
\hline \multirow[t]{4}{*}{ B } & Male & & 1 & & & 2 & & & & & 1 & 1 & 1 \\
\hline & Female & & & & & 1 & & 2 & 1 & & 1 & 1 & \\
\hline & Young & & & & & & & & & & & & 1 \\
\hline & $?$ & & & & & & & & & & & & \\
\hline \multirow[t]{4}{*}{$\bar{C}$} & Male & & & 4 & 1 & & & & & 1 & 2 & 1 & 2 \\
\hline & Female & & & & 1 & & & & & & & & \\
\hline & Young & & & & 1 & 1 & & & & & & & 2 \\
\hline & $?$ & & & & & & 2 & & & & & & 1 \\
\hline \multirow[t]{4}{*}{ D } & Male & & & & & & 1 & & & 2 & 1 & 3 & 2 \\
\hline & Female & & & & & & & & & & & & \\
\hline & Young & & & & & & & & & & & & \\
\hline & $?$ & & & & & & & & & & 1 & & \\
\hline \multirow[t]{4}{*}{$\bar{E}$} & Male & 3 & & & & & & 1 & 1 & 1 & 1 & 1 & 2 \\
\hline & Female & & 1 & & & & 1 & & & & & 1 & \\
\hline & Young & & & & & & & & & & & & \\
\hline & $?$ & & & & & & & & & & & & \\
\hline \multirow[t]{4}{*}{$F$} & Male & 2 & & & & & & & 3 & 1 & & & 1 \\
\hline & Female & & & 1 & & 1 & & & 1 & & & & \\
\hline & Young & & & & & & & & & & & & \\
\hline & $?$ & & & & & & & & & & & & \\
\hline \multirow[t]{4}{*}{$\bar{G}$} & Male & 1 & & & & & 1 & 1 & & 2 & 1 & & \\
\hline & Female & & & & & & 1 & 1 & & & & & \\
\hline & Young & & & & & & & & 1 & & & & \\
\hline & $?$ & & & & & & & & & & & & \\
\hline \multirow[t]{4}{*}{$\mathrm{H}$} & Male & & & & & & & & 2 & 1 & 1 & 1 & 2 \\
\hline & Female & & 1 & & 1 & 1 & & & & 1 & & 1 & \\
\hline & Young & & & & 1 & & & & & & & & \\
\hline & $?$ & & & & & & & & & & & & \\
\hline \multirow[t]{4}{*}{1} & Male & & & & 1 & & & & & & & & \\
\hline & Female & & & & & & & & & & & & \\
\hline & Young & & & & 1 & & & & & & & & \\
\hline & $?$ & & 1 & & & & & & & & & 1 & \\
\hline \multirow[t]{4}{*}{$\mathrm{J}$} & Male & & & & 1 & & & 1 & & & 2 & 4 & 2 \\
\hline & Female & & & & & & & & & & & & \\
\hline & Young & & & & & & & & & & & & 1 \\
\hline & $?$ & & & & & & & & 1 & 1 & & & \\
\hline \multirow[t]{4}{*}{$\mathrm{K}$} & Male & 1 & & & & & 1 & & 3 & & & & \\
\hline & Female & & & 1 & 1 & & & 1 & & & & & \\
\hline & Young & & & & & & & & & & & & \\
\hline & $?$ & & & & & & & & & & 1 & & 1 \\
\hline \multicolumn{2}{|l|}{ No. } & 4 & 5 & 4 & 5 & 5 & 5 & 8 & 6 & 7 & 8 & 9 & 8 \\
\hline
\end{tabular}

$?=$ not possible to differentiate between young birds and females, or korhaans that were heard but could not be designated as either male or female. 
while standing in roads and on termite mounds in both reserves $(n=20)$. By counting the number of males sighted on a monthly basis in the BGR, males were significantly more visible during October to December (Additional file 1: Table S1; $\chi^{2}=25.14, \mathrm{df}_{1,11}, p=0.0087$ ).

Conversely, females were more elusive than males. Adult males in both reserves approached playbacks, but this was never achieved with females (see also van Niekerk 2014). When males displayed, females in both reserves immediately turned their backs on the observer when they were encountered (or called with sound playback) and then escaped into nearby cover $(n=15)$.

\section{Group sizes, population and density}

The overall mean group sizes of the Red-crested Korhaan in the BGR was $1.07(n=238$, range $=1-3, \mathrm{SD}=0.29)$ and in the MNR $1.03(n=185$, range $=1-2, \mathrm{SD}=0.16)$. The difference between the two sites was not significant (ANOVA: $F=3.69, \mathrm{df}_{1,422}, p=0.06$ ). The highest mean group size of 1.66 in the BGR was recorded in February (Additional file 1: Table S1). The mean monthly group sizes in the BGR fluctuated marginally in a nonsignificant manner (Additional file 1 : Table S1; $\chi^{2}=2.72$, $\left.\mathrm{df}_{1,11}, p=0.993\right)$. The correlation between rainfall and mean group sizes in the BGR was insignificant (Additional file 1: Table S1; $r=-0.24, p>0.05$ ). The mean monthly population count in the BGR varied significantly $\left(\chi^{2}=\right.$ 36.35, $\mathrm{df}_{1,11}, p=0.0001$; Additional file 1: Table S1). The mean population size (the mean of three transect surveys per month) on the transect of the BGR was 5.83 in the mornings and 5.66 in the afternoons, with the difference not statistically significant (ANOVA: $F=0.025, \mathrm{df}_{1,22}, p=$ $0.87)$. In the transect area of the BGR, the density was 1 korhaan/42.6 ha (based on the overall mean monthly population calculated from Additional file 1: Table S1). The transect of the MNR was traversed on nine occasions to determine the density of korhaans (in December 2009, January 2010 and February 2011), where the mean density was 1 korhaan/38.57 ha. The difference between the two sites was not significant $\left(\chi^{2}=0.200, \mathrm{df}=1, p=0.65\right)$. There was no significant correlation between monthly density and rainfall in the BGR (Additional file 1: Table S1; $r=$ $-0.12, p>0.05$ ). However, density was more or less similar during September to December in the breeding season suggesting limited movement this time of the year in the population (Additional file 1: Table S1). The presence of males observed in the BGR population varied significantly from month to month $\left(\chi^{2}=24.08, \mathrm{df}_{1,11}, p=0.0124\right.$; also see Figure 2).

\section{Clusters}

The Red-crested Korhaan in the BGR lives in clusters throughout the year (A-K in Figure 1, Table 1). The term cluster is used because a number of males (2-4) and one or two females were recorded at these locations in close proximity to one another (5-70 $\mathrm{m}$ apart), in both reserves. These clusters occurred around the posts where males called one another actively during the start of the breeding season; in other words, the boundaries of these clusters were extended areas ( 2.4 ha) around these two or three calling posts (van Niekerk 2014). Six of these clusters (positions) in the BGR were used by males every year from 2009 to 2014 (JH van Niekerk, unpublished data).

Males targeted by means of playback during the breeding season often approached the source and then circled it for up to 20 min during playbacks. In one case a male flew up, displayed and flew towards the playback source, landing $10 \mathrm{~m}$ from it. In two cases, one in each reserve, one adult male was observed chasing another male in flight, as done by rival Northern black Korhaan (Afrotis afraoides) males on a territory ( $\mathrm{JH}$ van Niekerk, personal observation). From Table 1 it is evident that not all clusters were occupied every month. There were more clusters during the breeding season but the difference reported was statistically not significant $\left(x^{2}=6.66\right.$, $\mathrm{df}=11, p=0.85)$. Figure 1 also shows the appearance of floaters on the transect section among clusters A to D during October to November. These floaters were probably immature birds in adult plumage but not yet ready to breed.

\section{Distribution and landscape}

In the BGR, five clusters were associated with open spaces: one cluster (Figure 1A) was on ground eroded by overgrazing several decades ago; another (Figure 1D) was situated on overgrazed land with limited ground cover and sparsely dispersed trees; one overlapped with a local aeroplane landing strip (Figure 1C) and two clusters (Figure $1 \mathrm{H}$ and $\mathrm{J}$ ) overlapped with patches (2 ha and 10 ha respectively) of rocky outcrop. A sixth cluster was identified in an area that was burnt during August, which left the understory of the bush completely open and in which two males displayed actively in the open about $100 \mathrm{~m}$ apart from September to October. Permanent (more or less throughout the year, see Figure 1) clusters were not found in areas where there were thick stands of Terminalia sericea and Combretum tree species with bushes and grass beneath the canopy. However, the floaters in Figure 1A and B were observed in thick woodlands consisting mainly of Terminalia sericea trees and almost impenetrable ground cover. Solitary young birds also used these conditions for concealment.

Out of four clusters, occupied by the Red-crested Korhaan in the MNR, three overlapped with relatively open areas. Two of these clusters were situated next to a wide dirt road ( $\sim 20 \mathrm{~m}$ wide, including the road margins) and another cluster was situated around a drinking hole that was 
completely devoid of ground cover owing to years of trampling by antelopes, leaving just red desert sand and scattered Camel Thorn (Acacia erioloba) trees.

Out of 340 hours of observation in both reserves there was no evidence that korhaans moved to the dam in the BGR or water hole in the MNR to drink water (Table 1; Figure 1). In other words, there were no regular movements between home base and open water. From Figure 1 it is also evident that most clusters were situated further south, away from the southern shoreline of the Klipvoor Dam. However, they were seen actively feeding off green leaves and plant buds during winter, of which Asparagus spp. were regularly consumed in the BGR $(n=10)$.

\section{Discussion}

\section{Lek-formation}

Among southern Africa korhaans and bustards lekformation has only been described for Ludwig's and Kori Bustards (Allan 2005d and 2005e). This present survey indicated that adult Red-crested Korhaan males live in clusters, but these clusters are accordant with a combination of criteria that describe a lek put forward by Bradbury (1981) and Högland and Alatalo (1995):

\section{Males must not participate in parental care:} Red-crested Korhaan males did not participate in parental duties in either of the two reserves.

2. Males must aggregate to display: Red-crested Korhaan males gathered at traditional sites (year after year) in both reserves during the breeding season to display through sounds, aerial flights and by exposing their white breast feathers at each other, but breast feathers may also attract females. These korhaans formed dispersed leks, as opposed to the more classical definition of a lek being a small court area as proposed by Bradbury (1981), There were considerable distances of 40-100 m between competing males in the leks (van Niekerk 2014). Similar to the males of Ludwig's Bustard, Red-crested Korhaan males also defended the immediate areas around them within the dispersed lek by chasing approaching conspecific male intruders.

3. Females must select males from the lek to breed with: Red-crested Korhaan females approached displaying males in the lek (also see van Niekerk 2014).

4. Females must find resources in the lek: In terms of the non-classical definition of a lek, females must obtain more resources from the lek than just males (Högland and Alatalo 1995). Two Red-crested Korhaan females were observed with offspring in two established leks in both reserves which meant that they not only found males but also raised offspring in these leks. In light of this synthesis, I conclude that Red-crested Korhaans form leks.

\section{Population dispersion}

The Red-crested Korhaan population was dispersed in a clumped manner which is ascribed to lek-formation (Figure 1). The positions of leks were probably the result of leks being selected on the basis of habitat structure. The leks were located in open areas to maximize visual interaction between competing males and between males and females and to ensure that acoustic signals are transmitted effectively from signaller to receiver (Daniel and Blumstein 1998). These open conditions are less inclined to attenuate (degrade) sound frequencies. The higher frequencies of sounds are not excessively distorted in open vegetation (Catchpole and Slater 2008). Calls are a very prominent feature of the breeding behavior of the Red-crested Korhaan, given that males engage in continuous reciprocal calling to attract females during the breeding season (van Niekerk 2014). The temporary appearances and movements of single birds between the leks (floaters) during the breeding season, suggest that these korhaans attempt to join leks to compete for females.

\section{Group sizes}

The difference in the mean group sizes of the Red-crested Korhaan in both reserves $(\mathrm{MNR}=1.03 ; \mathrm{BGR}=1.07)$ was statistically not significant. Group sizes were not affected by climate despite the fact that the BGR receives about $650 \mathrm{~mm}$ rain per annum and the MNR only about $200 \mathrm{~mm}$. Theoretically, larger groups might have been expected in wetter climates that can be ascribed to higher survival levels as a result of more food resources (cf. Newton 1998). Instead, the solitary lifestyle of the Red-crested Korhaan might be a compromise between survival and available resources (food/moisture); such arid pockets are also inhabited in wetter climates. For example, undernourished birds in a korhaan population are apparently less resilient to environmental threats (e.g. disease and predation) than a single bird that is nourished (Chase et al. 2002).

\section{Water requirements}

The korhaans were not observed drinking water in the reserves and neither was there any indication of local movement in response to rainfall as was determined for the Northern Black Korhaan (Allan 2005a). However, according to Allan (2005f), the Red-crested Korhaan drinks water but this could be in cases when surface water was close by. The consistent occurrence of korhaans in fixed locations which were situated far from water in the BGR (based on morning and afternoon surveys along the same transect) suggests that korhaans do not undertake long daily journeys (>200 m). This is probably a strategy to prevent dehydration and to minimize predation. Instead, they consumed green seeds/buds, plant leaves and invertebrates locally, providing adequate moisture. 


\section{Sex ratios}

In both reserves the apparent sex ratios of the Red-crested Korhaan were skewed in favor of males, a fact also noted by Allan (2005f). Indeed, the elusive behavior of the female Red-crested Korhaan suggests that more females were present in the populations, but probably overlooked during field work. However, a sex ratio skewed in favor of males could explain the existence of leks among Red-crested Korhaan males. It is a mating strategy that enables females to select the fittest males from multiple choices ("good genes"; Hasselquist 1994).

\section{Density}

The density of Ludwig's Bustards was significantly correlated with monthly rainfall and their numbers have been reported to increase following good rains (Allan 2005d). No such monthly correlation was determined for the Red-crested Korhaan in the BGR (Additional file 1: Table S1).

The density (e.g. transect area divided by number of birds) of the Red-crested Korhaan can be used as a population index, in other words to assess the stability of a population, whether it increases or decreases (Sutherland et al. 2004). A substantial difference was reported between the densities of the Red-crested Korhaan from different studies. A density of 1 Red-crested Korhaan/ 42.6 ha in the BGR is lower than the reported densities of $1 / 18$ ha in the Kalahari and $1 / 25$ ha in the north east of South Africa (Allan 2005f). This survey revealed that various factors could affect bird counts such as the elusive behavior of females and seasonality. Various population sizes were counted in different months in the BGR (Additional file 1: Table S1). Males were more visible during the breeding season (September to December) which can be ascribed to active displaying and calling during lekking (Table 1). However, no difference was found between morning and afternoon population counts. The counting method (whether a line transect, point transect, lek monitoring or population counts) (Sutherland et al. 2004) and the months of the year in which the survey is conducted should be similar to obtain comparable data.

\section{Conclusions}

How is a polygynous system, compared to a monogamous system (e.g. Karroo Korhaan) beneficial to the survival of the Red-crested Korhaan? After all, only $5 \%$ of all bird species engage in polygyny (Hasselquist and Sherman 2001). Theoretically, in a monogamous system the male protects the resources of a territory, as well as his female and offspring for at least part of the year (Hasselquist 1994). The polygynous system of the Red-crested Korhaan appears to be disadvantageous. The solitary female raises one chick in arid conditions which leaves her care after 3 to 4 months. According to Allan (2005f) the brood size success average is 1.1. As well, the Red-crested Korhaan breeds seasonally which means that the early death of a chick is not replaced in the same year.

Indeed, polygyny does not contradict the solitary lifestyle of this korhaan (mean group sizes $<2$ ) since polygyny in this study infers that individuals only meet for a short while. A solitary lifestyle is probably a strategy by the Red-crested Korhaan to survive in arid conditions. On the other hand, polygyny combined with lekking increases the chances of a male to assert his reproductive output among females that live dispersedly and solitarily. Furthermore, in accordance with the theoretical views of Orians (1969), females in polygynous systems, such as Red-crested Korhaan females, may prefer to mate with already paired males in good habitat rather than monogamously with a male in a poor habitat. During the breeding period, all males were engaged in lek activities (e.g. calls, chases and aerial displays) which meant that male interlopers were not available to engage in extra-pair copulation. This could possibly contribute to a low juvenile count. Indeed, this does not exclude the possibility that females may copulate with more than one male during lekking but this would have been restricted to the breeding season.

The elusive behavior of Red-crested Korhaan females is ascribed to their solitary lifestyle. They are less vocal than males and invariably seek cover when confronted by intruders (van Niekerk 2014). One of the functions of grouping behavior would indeed be to provide more than one pair of eyes ("many-eyes hypothesis") to scan the area for predators (Pulliam 1973). Instead, the preference of female korhaans for cover compensates for the loss of shared predator surveillance that groups offer.

Lek-formation is the pivot of the mating system of the Red-crested Korhaan and affects the manner in which populations are dispersed. Should habitat management become important to conserve these korhaans, a landscape with openness for leks and patches with relatively dense scrub cover for females would constitute an important requirement. These annually used leks are social structures at fixed locations that field ecologists can use to monitor the number of leks and the number of males in a lek, i.e., population stability. A study on movement (with marked birds), diet and food availability may throw more light on the driving forces (intrinsic/extrinsic) that determine group sizes and dispersal strategies.

\section{Additional file}

Additional file 1: Table S1. Seasonal events, population and group sizes of the Red-crested Korhaan in the Borakalalo Game Park.

Competing interests

The author declares that she has no competing interests. 


\section{Acknowledgements}

I thank Ann-Elizabeth Jones for assistance during field excursions.

Received: 8 December 2014 Accepted: 9 December 2014

Published online: 24 December 2014

\section{References}

Allan DG (2005a) Northern Black Korhaan. In: Hockey PAR, Dean WJR, Ryan PG (eds) Roberts Birds of Southern Africa, 7th edn. Trustees of the John Voelcker Bird Book Fund, Cape Town, pp 298-300

Allan DG (2005b) Karoo Korhaan. In: Hockey PAR, Dean WJR, Ryan PG (eds) Roberts Birds of Southern Africa, 7th edn. Trustees of the John Voelcker Bird Book Fund, Cape Town, pp 301-302

Allan DG (2005c) Blue Korhaan. In: Hockey PAR, Dean WJR, Ryan PG (eds) Roberts Birds of Southern Africa, 7th edn. Trustees of the John Voelcker Bird Book Fund, Cape Town, pp 302-304

Allan DG (2005d) Ludwig's Bustard. In: Hockey PAR, Dean WJR, Ryan PG (eds) Roberts Birds of Southern Africa, 7th edn. Trustees of the John Voelcker Bird Book Fund, Cape Town, pp 293-294

Allan DG (2005e) Red-crested Korhaan. In: Hockey PAR, Dean WJR, Ryan PG (eds) Roberts Birds of Southern Africa, 7th edn. Trustees of the John Voelcker Bird Book Fund, Cape Town, pp 296-297

Allan DG (2005f) Kori Bustard. In: Hockey PAR, Dean WJR, Ryan PG (eds) Roberts Birds of Southern Africa, 7th edn. Trustees of the John Voelcker Bird Book Fund, Cape Town, pp 295-296

Allan DG, Anderson MD (2010) Assessment of the Threats Faced by South Africa's Bustard Species. Bustard Working Group, BirdLife South Africa

Bradbury TW (1981) The evolution of leks. In: Alexander RD, Tinkle DW (eds) Natural Selection and Social Behaviour. Chiron Press, New York and Concord, pp 138-169

Broders O, Osborne T, Wink M (2003) A mtDNA phylogeney of bustards (family Otididae) based on nucleotide sequences of the cytochrome b-gene. J Ornithol 144:176-185

Catchpole CK, Slater JB (2008) Bird Song: Biological Themes and Variation. Cambridge University Press, United Kingdom

Chase JM, Peter A, Abrams PA, Grover JP, Diehl PS, Robert C, Shane H, Richards DA, Nisbet RM, Case TJ (2002) The interaction between predation and competition: a review and synthesis. Ecol Let 5:302-315

Chittenden H, Allan D, Weiersbye I (2012) Roberts Geographic Variation of Southern African Birds. John Voelcker Bird Book Fund, Cape Town

Constantine M (2013) The Sound Approach to Birding. The Sound Approach, Dorset

Daniel JC, Blumstein DT (1998) A test of the acoustic adaptation hypothesis in four species of marmot. Anim Behav 56:1517-1528

Green RE (2004) Breeding Biology. In: Sutherland WJ, Newton I, Green RE (eds) Bird Ecology and Conservation. Oxford University Press, Oxford, pp 57-83

Hasselquist D (1994) Male Attractiveness, Mating Tactics and Realized Fitness in the Polygynous Great Reed Wabler, Thesis. Lund University, Lund, Sweden

Hasselquist D, Sherman PW (2001) Social mating systems and extrapair fertilization in passerine birds. Behav Ecol 12:457-466

Hitchcock RK, Yellen JE, Geldburd DJ, Osborn AJ, Crowell AL (1996) Subsistence hunting and resource management among the JU/HOASI of Northwestern Botswana. Afr Stud Monogr 17:153-220

Hockey PAR, Dean WJR, Ryan PG (eds) (2005) Roberts Birds of Southern Africa, 7th edn. The Trustees of the John Voelcker Bird Book Fund, Cape Town

Högland J, Alatalo RV (1995) Leks. Princeton University Press, Princeton

Kemp A, Tarboton W (1976) Small South Africa bustards. Bokmakierie 28:40-43

Khan WA, Mian A (2013) Population biology of Black Francolin (Francolinus francolinus) with reference to Lal Suhanra National Park, Pakistan. Pak J Zoo 45:183-191

Morales MB, Jiquet F, Arroyo B (2001) Exploded leks: what Bustards can teach us. Ardeola 48:85-98

Mucina L, Rutherford MC (eds) (2006) The vegetation of South Africa, Lesotho and Swaziland. Strelitzia 19. South African National Biodiversity Institute Pretoria

Newton I (1998) Population Limitations in Birds. Academic, Amsterdam Odum EP (1971) Fundamentals of Ecology, 3rd edn. WB Saunders, Philadelphia

Orians GH (1969) Age and hunting success in the Brown Pelican (Pelecanus occidenralis). Anim Behav 55:107-121

Pulliam HR (1973) On the advantages of flocking. J Theoret Biol 38:419-422
Sutherland WJ, Newton I, Green RE (2004) Bird Ecology and Conservation. Oxford University Press, New York

Tarboton WR, Kemp MI, Kemp AC (1987) Birds of the Transvaal. Transvaal Museum, Pretoria

van Niekerk JH (2014) Vocal behaviour of the red-crested Korhaan Lophotis ruficrista in South Africa. S Afr J Wildl Manage 44:24-31

Whitehead H (2008) Analyzing Animal Societies; Quantitative Methods for Vertebrate Social Analysis. University of Chicargo Press, London

\section{Submit your next manuscript to BioMed Central and take full advantage of:}

- Convenient online submission

- Thorough peer review

- No space constraints or color figure charges

- Immediate publication on acceptance

- Inclusion in PubMed, CAS, Scopus and Google Scholar

- Research which is freely available for redistribution

Submit your manuscript at www.biomedcentral.com/submit 